\title{
The Impact of Structural Reforms on Environmental Problems in Agriculture
}

\author{
AKHTAR A. HAI
}

\section{INTRODUCTION}

With the technological advancement in almost every sphere of human life, there has been an increased tendency to focus on the conservation of scarce resources by acquiring higher levels of resource use efficiency in the production process. However, there also remains a visible element of haste in policy planning towards the achievement of these goals, particularly in the developing world.

The economic viability of such haste would have been positive had this helped in reducing the social cost of delayed policy actions taken in the preceding period. Conversely, the policy planning efforts continue to be ignorant of long-term consequences of current actions, as well as deficient in integrating various components of the sector or sub-sector of the economy which can not be viewed in isolation. These design defects in policies are largely ignored in post-impact evaluations of programmes, and failures are often incorrectly attributed to implementation, or simply referred to as managerial snags. Nevertheless, these inherent design defects become the primary contributors towards non-sustainability of development programmes.

Pakistan's agriculture, with its declining share in the economy over time, is still the single largest sector accounting for 23 percent in the GDP. Whereas its share has steadily declined in favour of rising manufacturing and services sectors, its rate of growth has remained rather erratic.

In addition to the vagaries of weather, its place in the national policy planning has remained quite vagrant over time. The dwindling status accorded to the agricultural sector by the earlier development prescriptions, which interchangeably emphasised on growth or employment-led strategies, largely neglected issues related to resource mobilisation and sustainability of the process which could have generated growth or employment.

It is obvious that any strategy for development with an exclusive reliance on the productivity of the system is bound to overlook the other conditionalities in insuring sustainability, namely, stability and equatability of the system. By ignoring the aspects related to the stability of a production system, particularly in agriculture, Karachi.

Akhtar A. Hai is Research Economist at the Applied Economics Research Centre, University of the logical consequence of environmental degradation leads to non-sustainability of 
the resources employed in the production process. The inequity in the distribution of benefits of growth across various groups of producers further aggravates the problem.

These complexities generated over time have now tended to accumulate in the form of serious water and soil problems, generally referred to as waterlogging and salinity. This menace at present poses a great threat to the stability of the Indus Basin.

The factors favouring an efficient capital formation in Pakistan's agriculture should logically focus on environmental degradation in addition to the various fiscal and monetary policies designed for the agricultural sector in the past to promote agricultural production.

\section{MACROECONOMIC POLICIES}

The macroeconomic policies for the agricultural sector had largely been made in the background of growth-oriented strategy for sectoral development. However, the instrument of pricing policy regulations had imposed disguised taxes on agriculture (thereby restricting the growth of investment fund) instead of providing incentives to improve resource use efficiency of the factors employed, particularly of land and water.

In a dynamic sense, however, the losses to the economy are far greater than those mentioned above. The environmental damages attributable to government policies towards agriculture have tended to threaten the stability of the agriculture production system. These damages include (but are not limited to) the following:

(i) increase in waterlogging, restricting the supply of cultivable land;

(ii) salinisation of soil and water resources, restricting plant growth;

(iii) overgrazing of land;

(iv) deforestation; and

(v) soil exhaustion.

\subsection{Environmental Problems}

Any change caused either by natural or deliberate human action brings further changes in the surroundings and, thus, a chain of reactions is observed which ultimately alter the environment. Sometimes environmental changes occur due to external factors for which the project design is not directly to be held responsible. On the contrary, certain projects create additional changes that are internally determined and are generally not accounted for at the design stage. However, in either case, the project fails to yield the expected benefits and, in certain cases, it ceases to operate long before its designed life-span. 
The tendency to avoid or ignore the possible environmental degradation in a society which is not conscious of its ultimate impact does not remain limited to one project only. Rather, such a silence spreads over its entire process of policy planning. Thus the transmitting the effluent of one scheme to its neighbourhood in the form of negative spill-over effects (i.e., negative externality) ultimately affects the performance of the entire economy. The problem becomes more acute when a project creates environmental degradation within its own jurisdiction by ignoring it at the stage of project preparation.

Societies which are cognizant of such environmental impacts have followed policies either to reverse the potential impact or to impose a cost on those who create pollution. In the process, the enactment of appropriate regulatory measures becomes an integral part of the policy planning and a sacred duty of the government concerned.

\section{ROLE OF GOVERNMENT}

Government intervention through various fiscal and monetary measures to provide economic incentives for higher growth of the economy, and the regulatory framework to ensure sustainability of scarce resources used in the production process, are vital for sustainable development. However, what is even more important is the simultaneity required between these two types of interventions in order that sustainable development is achieved and long-run gains in efficiency and equity are realised. In the absence of effective interventions, individuals or groups of individuals tend to assign a high discount rate to the future by achieving short-run gains at the cost of long-run losses.

Ironically, the governments have often intervened either to depress producer prices and/or to perpetuate subsidies, thereby reducing the prospects for generating investment funds and increasing the misallocation of resources. In Pakistan, the role of government in the past in terms of policy interventions has remained somewhat misplaced. This has happened more so towards the agricultural sector, which is still the largest sector of the economy.

In the light of these, this paper attempts to measure the potential impact on environmental problems in agriculture with particular reference to the structural reforms initiated by the government on the recommendations of the World Bank and the International Monetary Fund (IMF). It quantifies the likely impact of structural reforms on the waterlogging and salinity levels, which are key environmental problems faced in the agricultural sector.

\subsection{Structural Reforms in Agriculture}

The Structural Adjustment Programme implemented in 1988 was based on the initiatives taken by the World Bank and the IMF. Like other sectors of the economy, the programme was persued in the agricultural sector. 
The goals of the programme clearly highlight the need for short-run policy changes to redress the input and output pricing in agriculture and to improve the efficiency of irrigation water distribution. It also calls for long-term policies to develop research, marketing, and irrigation systems to improve levels of technical efficiency in agriculture. However, these policy measures are largely driven by the growth-led strategies and do not spell out the environmental degradation that may continue in the long run.

In the process of measuring the linkage effects between macro policy variables and environment in the agricultural sector, the following issues need attention:

- In the context of price policies and subsidies in agriculture, it would be important to analyse the impact of changes in the relative price structure of various crops (signalled through changes in crop mix) on soil quality.

- The low levels of crop yields may not only signal towards the inefficiency in the use of resources specific to crops. Rather, improper and/or insufficient applications of inputs may also result in the form of deterioration in land and water quality.

- In the absence of proper drainage network in the Indus Basin, it would be relevant to analyse the impact of crop intensification to the extent it is caused by the macro policies on soil degradation. This will indicate the adherence of water sector development expenditure to the impact of price policies.

- In the event the farmers face differential access to the benefits reposed in the price and incentives policy package, the likely impact on the growth of rural poverty may suggest additional threats to the environment.

\section{MEASUREMENT OF ENVIRONMENTAL IMPACT}

The estimates on the levels of groundwater balance and salt additions at the sub-surface level as an outcome of changes in agricultural output prices under the structural reform package were obtained using the Indus Basin Model Revised (IBMR) developed by the World Bank.

The model is found useful in measuring the impact of specific policy (or project) changes on cropping pattern, resource use, output levels, and groundwater and salt balances by altering agricultural production technologies and/or resource availability.

The model was tested with incremental changes in the price levels of cotton, irri rice, irrigation water, and fertiliser. Subsequently, the price changes were brought to the levels conducive to the adjustment policies to remove all price distortions by following international prices for all commodities being investigated. 
IBMR divides the entire Indus Basin into 9 agroclimatic zones (ACZs). The analysis presented in the paper covers two zones, namely, PCW (Punjab CottonWheat) and SRWN (Sindh Rice-Wheat North), to focus on the cotton and rice crops, which have been duly emphasised in the Structural Adjustment Programme designed for the agricultural sector.

PCW covers nearly 80 percent of cotton acreage and 66 percent of canal command area (CCA) in Punjab province, whereas SRWN covers 60 percent of acreage under rice and 32 percent of CCA in Sindh province.

\section{Data Sources and Assumptions for Different Scenarios}

IBMR provides a multi-disciplinary approach (i.e., economics, agronomy, irrigation) in capturing the impact of policy changes on various aspects of agricultural system. It, therefore, uses data from various sources within each discipline.

As a linear programming tool, it uses detailed sets of economic data from primary as well as secondary sources. The farm level data of 500 farms collected by WAPDA under Extended Agricultural Economics Survey (EAES) has regularly been supplemented by additional surveys covering the period till 1988. The current data base also reflects the cumulative knowledge acquired during the project studies, such as On-Farm Water Management, Left Bank Outfall Drain, and Kalabagh Agricultural Impact Study. The detailed information collected from Agricultural Prices Commission, Censuses of Agriculture, and Livestock and Agricultural Machinery also form part of the data base used in IBMR.

The analysis uses 1987-88 as the base year for all comparison purposes. This year is also the first year of structural adjustment programme. For the static picture of 1987-88, a set of scenarios was generated with various price assumptions.

The purpose of taking such scenarios was to analyse the sensitivity of the cropping mix to price changes and subsequent impact on groundwater balance and salt additions. In forecasting the salt balances, IBMR uses calibrations to project the impact till year 2000 .

\subsection{Results*}

The results have been presented through Tables 1 to 3 covering both fresh and saline areas of PCW and SRWN. In comparing the results across zones, it should be noted that over 87 percent of CCA in PCW is underlain with fresh water. The corresponding level for SRWN is only 51 percent.

\footnotetext{
*This paper presents summary results only. A detailed discussion on the results was presented in the paper read at the Conference.
} 
Table 1(a)

Impact of Changes in Input/Output Prices on the Cropping Pattern Across Fresh Areas of PCW \& SRWN

\begin{tabular}{|c|c|c|c|c|c|c|c|c|c|c|c|c|c|c|}
\hline \multirow[b]{3}{*}{ CROPS } & \multicolumn{7}{|c|}{$\begin{array}{l}\text { PCW (FRESH) } \\
\text { Scenarios }\end{array}$} & \multicolumn{7}{|c|}{$\begin{array}{c}\text { SRWN (FRESH) } \\
\text { Scenarios }\end{array}$} \\
\hline & \multirow[t]{2}{*}{$\begin{array}{c}1 \\
\text { Base Year } \\
1987-88\end{array}$} & \multirow{2}{*}{$\begin{array}{l}\text { A Solitary } \\
\text { Cotton }\end{array}$} & \multicolumn{2}{|c|}{$\begin{array}{c}3 \\
\text { y } 10 \% \text { Increase in the } \\
\text { Price of }\end{array}$} & \multirow{2}{*}{$\begin{array}{c}5 \\
10 \% \\
\text { Increase } \\
\text { (Combined) }\end{array}$} & \multirow{2}{*}{$\begin{array}{c}6 \\
\text { International } \\
\text { Prices of } \\
\text { Com. Group }\end{array}$} & \multirow{2}{*}{$\begin{array}{c}7 \\
\text { Inter. } \\
\text { Prices of } \\
\text { all Major } \\
\text { Inputs \& } \\
\text { Outputs } \\
\end{array}$} & \multirow[t]{2}{*}{$\begin{array}{c}1 \\
\text { Base Year } \\
1987-88\end{array}$} & \multicolumn{3}{|c|}{$\begin{array}{l}\text { A Solitary } 10 \% \text { Increase in the } \\
\text { Price of }\end{array}$} & \multirow{2}{*}{$\begin{array}{c}5 \\
10 \% \\
\text { Increase } \\
\text { (Combined) }\end{array}$} & \multirow{2}{*}{$\begin{array}{c}6 \\
\text { Inter. } \\
\text { Prices of } \\
\text { Com. Group }\end{array}$} & \multirow{2}{*}{$\begin{array}{c}7 \\
\text { Inter. } \\
\text { Prices of } \\
\text { all Major } \\
\text { Inputs \& } \\
\text { Outputs } \\
\end{array}$} \\
\hline & & & Water & Fertiliser & & & & & Irri. Rice & Water & Fertiliser & & & \\
\hline CCA & 8,795 & 8,795 & 8,795 & 8,795 & 8,795 & 8,795 & 8,795 & 1,576 & 1,576 & 1,576 & 1,576 & 1,576 & 1,576 & 1,576 \\
\hline Annual Total & 14,366 & 14,642 & 14,369 & 14,368 & 14,491 & 14,873 & 15,924 & 1,552 & 1,552 & 1,552 & 1,553 & 1,553 & 1,553 & 1,958 \\
\hline Rabi Total & 7,752 & 7,760 & 7,755 & 7,752 & 7,751 & 7,734 & 8,784 & 1,155 & 1,155 & 1,155 & 1,156 & 1,155 & 1,156 & 1,563 \\
\hline Wheat & 5,692 & 5,692 & 5,692 & 5,692 & 5,692 & 5,692 & 6,591 & 992 & 992 & 992 & 993 & 994 & 993 & 1,458 \\
\hline Gram & 747 & 747 & 747 & 747 & 747 & 747 & 733 & 15 & 15 & 15 & 15 & 15 & 15 & 15 \\
\hline R. \& Must & 277 & 277 & 277 & 277 & 273 & 264 & 264 & 85 & 85 & 85 & 85 & 83 & 85 & 18 \\
\hline R. Fodder & 232 & 240 & 235 & 232 & 235 & 214 & 369 & 18 & 18 & 18 & 18 & 18 & 18 & 58 \\
\hline Potatoes & 58 & 58 & 58 & 58 & 58 & 58 & 54 & 10 & 10 & 10 & 10 & 10 & 10 & 4 \\
\hline Onion & 43 & 43 & 43 & 43 & 43 & 43 & 43 & 9 & 9 & 9 & 9 & 9 & 9 & 8 \\
\hline S. Cane-M & 242 & 242 & 242 & 242 & 242 & 242 & 269 & 24 & 24 & 24 & 24 & 24 & 24 & - \\
\hline S. Cane-G & 161 & 161 & 161 & 161 & 161 & 161 & 161 & 2 & 2 & 2 & 2 & 2 & 2 & 2 \\
\hline Orchards & 300 & 300 & 300 & 300 & 300 & 300 & 300 & - & - & - & - & - & - & - \\
\hline Kharif Total & 6,614 & 6,882 & 6,614 & 6,614 & 6,740 & 7,049 & 7,140 & 397 & 397 & 397 & 397 & 398 & 397 & 395 \\
\hline Cotton & 5,242 & 5,510 & 5,242 & 5,242 & 5,365 & 5,510 & 5,522 & - & - & - & - & - & - & - \\
\hline Basmati & 518 & 518 & 518 & 518 & 518 & 505 & 557 & - & - & - & - & - & - & \\
\hline Irri & 112 & 112 & 112 & 112 & 115 & 292 & 292 & 332 & 332 & 332 & 332 & 333 & 332 & 338 \\
\hline Kh. Fodder & & - & - & - & - & - & - & 26 & 26 & 26 & 26 & 26 & 26 & 42 \\
\hline Chilli & 23 & 23 & 23 & 23 & 23 & 23 & 23 & 13 & 13 & 13 & 13 & 13 & 13 & 13 \\
\hline Maize & 16 & 16 & 16 & 16 & 16 & 16 & 16 & - & - & - & - & - & - & - \\
\hline S. Cane-M & 242 & 242 & 242 & 242 & 242 & 242 & 269 & 24 & 24 & 24 & 24 & 24 & 24 & - \\
\hline S. Cane-G & 161 & 161 & 161 & 161 & 161 & 161 & 161 & 2 & 2 & 2 & 2 & 2 & 2 & 2 \\
\hline Orchards & 300 & 300 & 300 & 300 & 300 & 300 & 300 & - & - & - & - & - & - & - \\
\hline \multicolumn{15}{|l|}{$\begin{array}{l}\text { Cropping } \\
\text { Intensity \% }\end{array}$} \\
\hline Annual & 163 & 166 & 163 & 163 & 165 & 168 & 181 & 98 & 98 & 98 & 98 & 98 & 98 & 124 \\
\hline Rabi & 88 & 88 & 88 & 88 & 88 & 88 & 100 & 73 & 73 & 73 & 73 & 73 & 73 & 99 \\
\hline Kharif & 75 & 78 & 75 & 75 & 77 & 80 & 81 & 25 & 25 & 25 & 25 & 25 & 25 & 25 \\
\hline
\end{tabular}


Table 1(b)

Impact of Changes in Input/Output Prices on the Cropping Pattern Across Saline Areas of PCW \& SRWN

\begin{tabular}{|c|c|c|c|c|c|c|c|c|c|c|c|c|c|c|}
\hline \multirow{3}{*}{ CROPS } & \multicolumn{7}{|c|}{$\begin{array}{c}\text { PCW (SALINE) } \\
\text { Scenarios }\end{array}$} & \multicolumn{7}{|c|}{$\begin{array}{c}\text { SRWN (SALINE) } \\
\text { Scenarios }\end{array}$} \\
\hline & \multirow{2}{*}{$\begin{array}{c}\text { Base Year } \\
1987-88\end{array}$} & \multicolumn{3}{|c|}{$\begin{array}{l}2 \\
\text { A Solitary } 10 \% \text { Increase in the } \\
\text { Price of } \\
\end{array}$} & \multirow{2}{*}{$\begin{array}{c}5 \\
10 \% \\
\text { Increase } \\
\text { (Combined) }\end{array}$} & \multirow{2}{*}{$\begin{array}{c}6 \\
\text { International } \\
\text { Prices of } \\
\text { Com. Group }\end{array}$} & \multirow{2}{*}{$\begin{array}{c}7 \\
\text { Inter. } \\
\text { Prices of } \\
\text { all Major } \\
\text { Inputs \& } \\
\text { Outputs } \\
\end{array}$} & \multirow{2}{*}{$\begin{array}{c}\text { Base Year } \\
1987-88\end{array}$} & \multicolumn{3}{|c|}{$\begin{array}{c}2 \\
\text { A Solitary } 10 \% \text { Increase in the } \\
\text { Price of }\end{array}$} & \multirow{2}{*}{$\begin{array}{c}5 \\
10 \% \\
\text { Increase } \\
\text { (Combined) }\end{array}$} & \multirow{2}{*}{$\begin{array}{c}6 \\
\text { Inter. } \\
\text { Prices of } \\
\text { Com. Group }\end{array}$} & \multirow{2}{*}{$\begin{array}{c} \\
\text { Inter. } \\
\text { Prices o } \\
\text { all Majo } \\
\text { Inputs \& } \\
\text { Outputs }\end{array}$} \\
\hline & & & Water & Fertiliser & & & & & Irri.Rice & Water & Fertiliser & & & \\
\hline CCA & 2,450 & 2,450 & 2,450 & 2,450 & 2,450 & 2,450 & 2,450 & 2,819 & 2,819 & 2,819 & 2,819 & 2,819 & 2,819 & 2,819 \\
\hline Annual Total & 2,337 & 2,337 & 2,337 & 2,337 & 2,337 & 2,337 & 2,353 & 1,552 & 1,552 & 1,552 & 1,553 & 1,553 & 1,552 & 1,692 \\
\hline Rabi Total & 1,120 & 1,120 & 1,120 & 1,120 & 1,120 & 1,120 & 1,133 & 778 & 778 & 778 & 779 & 778 & 778 & 902 \\
\hline Wheat & 484 & 484 & 484 & 484 & 484 & 484 & 484 & 514 & 514 & 514 & 514 & 513 & 514 & 513 \\
\hline Gram & 34 & 34 & 34 & 34 & 34 & 34 & 34 & 89 & 89 & 89 & 90 & 90 & 89 & 88 \\
\hline R. \& Must & 12 & 12 & 12 & 12 & 12 & 12 & 12 & 37 & 37 & 37 & 37 & 37 & 37 & 87 \\
\hline R. Fodder & 45 & 45 & 45 & 45 & 45 & 45 & 46 & 120 & 120 & 120 & 120 & 120 & 120 & 168 \\
\hline Potatoes & 2 & 2 & 2 & 2 & 2 & 2 & 2 & 4 & 4 & 4 & 4 & 4 & 4 & 8 \\
\hline Onion & 2 & 2 & 2 & 2 & 2 & 2 & 2 & 3 & 3 & 3 & 3 & 3 & 3 & 3 \\
\hline S. Cane-M & 523 & 523 & 523 & 523 & 523 & 523 & 535 & - & - & - & - & - & - & 24 \\
\hline S. Cane-G & 18 & 18 & 18 & 18 & 18 & 18 & 18 & 4 & 4 & 4 & 4 & 4 & 4 & 4 \\
\hline Orchards & - & - & - & - & - & - & - & 7 & 7 & 7 & 7 & 7 & 7 & 7 \\
\hline Kharif Total & 1,217 & 1,217 & 1,217 & 1,217 & 1,217 & 1,217 & 1,220 & 774 & 774 & 774 & 774 & 775 & 774 & 790 \\
\hline Cotton & 616 & 616 & 616 & 616 & 616 & 616 & 604 & - & - & - & - & - & - & - \\
\hline Basmati & 7 & 7 & 7 & 7 & 7 & 7 & 7 & - & - & - & - & - & - & - \\
\hline Irri & 3 & 3 & 3 & 3 & 3 & 3 & 3 & 653 & 653 & 653 & 653 & 653 & 653 & 647 \\
\hline Kh. Fodder & 3 & 3 & 3 & 3 & 3 & 3 & 6 & 106 & 106 & 106 & 106 & 106 & 106 & 104 \\
\hline Chilli & 45 & 45 & 45 & 45 & 45 & 45 & 45 & 4 & 4 & 4 & 4 & 4 & 4 & 4 \\
\hline Maize & 2 & 2 & 2 & 2 & 2 & 2 & 2 & - & - & - & - & - & - & - \\
\hline S. Cane-M & 523 & 523 & 523 & 523 & 523 & 523 & 535 & $\begin{array}{ll}- \\
-\end{array}$ & - & $\begin{array}{ll}- \\
-\end{array}$ & - & 1 & - & 24 \\
\hline S. Cane-G & 18 & 18 & 18 & 18 & 18 & 18 & 18 & 4 & 4 & 4 & 4 & 4 & 4 & 4 \\
\hline Orchards & - & - & - & - & - & - & - & 7 & 7 & 7 & 7 & 7 & 7 & 7 \\
\hline \multicolumn{15}{|l|}{$\begin{array}{l}\text { Cropping } \\
\text { Intensity \% }\end{array}$} \\
\hline Annual & 95 & 95 & 95 & 95 & 95 & 95 & 96 & 55 & 55 & 55 & 55 & 55 & 55 & 60 \\
\hline Rabi & 46 & 46 & 46 & 46 & 46 & 46 & 49 & 28 & 28 & 28 & 28 & 28 & 28 & 32 \\
\hline Kharif & 49 & 49 & 49 & 49 & 49 & 49 & 50 & 27 & 27 & 27 & 27 & 27 & 27 & 28 \\
\hline
\end{tabular}


Table 2

Impact of Changes in Input/Output Prices on Ground Water Balance in Fresh and Saline Areas

\begin{tabular}{|c|c|c|c|c|c|c|c|c|c|c|c|c|c|c|}
\hline & \multicolumn{7}{|c|}{$\begin{array}{c}\text { PCW } \\
\text { Scenarios }\end{array}$} & \multicolumn{7}{|c|}{$\begin{array}{c}\text { SRWN } \\
\text { Scenarios }\end{array}$} \\
\hline & \multirow[t]{2}{*}{$\begin{array}{c}1 \\
\text { Base Year } \\
1987-88\end{array}$} & \multirow{2}{*}{$\begin{array}{l}\stackrel{2}{2} \\
\text { A Solitary } \\
\text { Cotton }\end{array}$} & \multicolumn{2}{|c|}{$\begin{array}{l}3 \\
3 \\
10 \% \text { Increase in the } \\
\text { Price of }\end{array}$} & \multirow{2}{*}{$\begin{array}{c}5 \\
10 \% \\
\text { Increase } \\
\text { (Combined) }\end{array}$} & \multirow{2}{*}{$\begin{array}{c}6 \\
\text { International } \\
\text { Prices of } \\
\text { Com. Group } \\
\\
\end{array}$} & \multirow{2}{*}{$\begin{array}{c}7 \\
\text { Inter. } \\
\text { Prices of } \\
\text { all Major } \\
\text { Inputs \& } \\
\text { Outputs } \\
\end{array}$} & \multirow[t]{2}{*}{$\begin{array}{c}1 \\
\text { Base Year } \\
1987-88\end{array}$} & \multicolumn{3}{|c|}{$\begin{array}{l}\text { A Solitary } 10 \% \text { Increase in the } \\
\text { Price of }\end{array}$} & \multirow{2}{*}{$\begin{array}{c}5 \\
10 \% \\
\text { Increase } \\
\text { (Combined) }\end{array}$} & \multirow{2}{*}{$\begin{array}{c}6 \\
\text { Inter. } \\
\text { Prices of } \\
\text { Com. Group }\end{array}$} & \multirow{2}{*}{$\begin{array}{c}7 \\
\text { Inter. } \\
\text { Prices of } \\
\text { all Major } \\
\text { Inputs \& } \\
\text { Outputs } \\
\end{array}$} \\
\hline & & & Water & Fertiliser & & & & & Irri. Rice & Water & Fertiliser & & & \\
\hline \multicolumn{15}{|l|}{ Fresh Areas } \\
\hline (a) Seepage & 16.919 & 17. 063 & 16.920 & 16.919 & 16.986 & 17.204 & 17.817 & 1.867 & 1.867 & 1.867 & 1.867 & 1.867 & 1.867 & 2.046 \\
\hline $\begin{array}{l}\text { (b) Water } \\
\text { Extraction }\end{array}$ & 16.616 & 17.246 & 16.621 & 16.616 & 16.908 & 17.903 & 20.662 & 1.627 & 1.627 & 1.627 & 1.627 & 1.627 & 1.627 & 2.387 \\
\hline $\begin{array}{l}\text { (c) Balance } \\
\text { (a-b) }\end{array}$ & 0.303 & -1.83 & 0.299 & 0.303 & 0.078 & -0.699 & -2.846 & 0.240 & 0.240 & 0.240 & 0.240 & 0.240 & 0.240 & -0.342 \\
\hline (d) Evaporation & n $\quad 0.111$ & 0.111 & 0.111 & 0.111 & 0.078 & 0.111 & 0.111 & 0.240 & 0.240 & 0.240 & 0.240 & 0.240 & 0.240 & 1.324 \\
\hline $\begin{array}{l}\text { (e) Net Balance } \\
\text { (c-d) }\end{array}$ & e 0.192 & -0.295 & 0.188 & 0.192 & 0.00 & -0.810 & -2.957 & 0.00 & 0.00 & 0.00 & 0.00 & 0.00 & 0.00 & -1.665 \\
\hline \multicolumn{15}{|l|}{ Saline Areas } \\
\hline (a) Seepage & 4.227 & 4.228 & 4.227 & 4.227 & 4.228 & 4.225 & 4.222 & 2.953 & 2.953 & 2.953 & 2.952 & 2.952 & 2.952 & 2.946 \\
\hline $\begin{array}{l}\text { (b) Water } \\
\text { Extraction }\end{array}$ & - & - & - & - & - & - & - & - & - & - & - & - & - & - \\
\hline $\begin{array}{l}\text { (c) Balance } \\
\text { (a-b) }\end{array}$ & 4.227 & 4.228 & 4.227 & 4.228 & 4.228 & 4.225 & 4.222 & 2.953 & 2.953 & 2.953 & 2.953 & 2.952 & 2.952 & 2.946 \\
\hline (d) Evaporation & n 3.378 & 3.378 & 3.378 & 3.378 & 3.378 & 3.378 & 3.378 & 2.953 & 2.953 & 2.953 & 2.952 & 2.952 & 2.952 & 2.946 \\
\hline $\begin{array}{l}\text { (e) Net Balance } \\
\text { (c-d) }\end{array}$ & e $\quad 0.849$ & 0.850 & 0.850 & 0.849 & 0.849 & 0.847 & 0.844 & 0.00 & 0.00 & 0.00 & 0.00 & 0.00 & 0.00 & 0.00 \\
\hline
\end{tabular}


Table 3

Impact of Price Increase on Groundwater Salt Balance in Fresh and Saline Areas

\begin{tabular}{|c|c|c|c|c|c|c|c|c|c|c|c|c|c|c|}
\hline & \multicolumn{7}{|c|}{$\begin{array}{c}\text { PCW } \\
\text { Scenarios }\end{array}$} & \multicolumn{7}{|c|}{$\begin{array}{c}\text { SRWN } \\
\text { Scenarios }\end{array}$} \\
\hline & \multirow[t]{2}{*}{$\begin{array}{c}1 \\
\text { Base Year } \\
1987-88\end{array}$} & \multirow{2}{*}{$\begin{array}{c}\stackrel{2}{2} \\
\text { A Solitar } \\
\\
\text { Cotton }\end{array}$} & \multicolumn{2}{|c|}{$\begin{array}{l}\text { ry } 10 \% \text { Increase in the } \\
\text { Price of }\end{array}$} & \multirow{2}{*}{$\begin{array}{c}\mathrm{b} \\
10 \% \\
\text { Increase } \\
\text { (Combined) }\end{array}$} & \multirow{2}{*}{$\begin{array}{c}6 \\
\text { International } \\
\text { Prices of } \\
\text { Com. Group }\end{array}$} & \multirow{2}{*}{$\begin{array}{c}7 \\
\text { Inter. } \\
\text { Prices of } \\
\text { all Major } \\
\text { Inputs \& } \\
\text { Outputs }\end{array}$} & \multirow[t]{2}{*}{$\begin{array}{c}1 \\
\text { Base Year } \\
1987-88\end{array}$} & \multicolumn{3}{|c|}{$\begin{array}{l}\text { A Solitary } 10 \% \text { Increase in the } \\
\text { Price of }\end{array}$} & \multirow{2}{*}{$\begin{array}{c}5 \\
10 \% \\
\text { Increase } \\
\text { (Combined) }\end{array}$} & \multirow{2}{*}{$\begin{array}{c}6 \\
\text { Inter. } \\
\text { Prices of } \\
\text { Com. Group }\end{array}$} & \multirow{2}{*}{$\begin{array}{c}7 \\
\text { Inter. } \\
\text { Prices of } \\
\text { all Majo } \\
\text { Inputs \& } \& \text { Outputs }\end{array}$} \\
\hline & & & Water & Fertiliser & & & & & Irri. Rice & Water & Fertiliser & & & \\
\hline \multicolumn{15}{|c|}{ Fresh Areas } \\
\hline \multicolumn{15}{|c|}{$\begin{array}{l}\text { Total Salt } \\
\text { Accumulation }\end{array}$} \\
\hline 1988 & 118.90 & 118.87 & 118.89 & 118.89 & 118.85 & 118.85 & 118.77 & 163.59 & 163.59 & 163.59 & 163.59 & 163.59 & 163.59 & 163.33 \\
\hline 1993 & 122.40 & 122.36 & 122.39 & 122.38 & 122.38 & 122.33 & 122.18 & 165.96 & 165.96 & 165.95 & 165.95 & 165.95 & 165.95 & 165.56 \\
\hline 2000 & 127.23 & 127.20 & 127.23 & 127.22 & 127.22 & 127.16 & 126.97 & 170.19 & 170.19 & 170.18 & 170.20 & 170.20 & 170.19 & 169.70 \\
\hline
\end{tabular}

Saline Areas

1. Drained Saline Area

Total Salt Accumulation

$\begin{array}{lllllllllllll}1988 & 296.69 & 296.69 & 296.69 & 296.69 & 296.69 & 296.65 & 296.62 & - & - & - & - & - \\ 1993 & 288.74 & 288.74 & 288.74 & 288.73 & 288.73 & 288.52 & 288.35 & - & - & - & - & - \\ 2000 & 275.74 & 275.73 & 275.74 & 275.72 & 275.71 & 275.28 & 274.90 & - & - & - & - & - \\ \\ \end{array}$




\section{Cropping Pattern Changes}

The changes in cropping pattern across various scenarios are presented in Table 1(a) and (b). It appears that

In fresh areas, cotton acreage has a consistent response to a 10 percent unilateral increase in its domestic price, and to a simultaneous increase of prices of 4 commodities in world prices. The irri rice shows only a marginal increase with the full impact of price changes, i.e., in Scenario 7. Acreages to sugarcane and orchards show insignificant change or no change at all.

Wheat acreage drastically increased but only with full price impact (Scenario 7), under which a significant increase in rabi fodder and a significant reduction in rapeseed acreage in SRWN takes place.

The cropping intensities remain unchanged until Scenario 6. Only the full price impact leads to a significant increase of 8 and 26 percent in PCW and SRWN, respectively. On the whole, it appears that changes in minor crops are largely adjustment factors related to the changes in acreages of the major crops in each zone as long as partial or restricted changes in prices are introduced (i.e., upto Scenario 6). The farmers seem motivated to go for an all-out increase in cropped area once international prices for all commodities are offered as reflected through the changes in cropping intensities. In other words, private investments in farming are likely to increase with a liberalised policy towards agricultural pricing.

In saline areas, however, the prospects for changes in crop acreages are rather slow even with full price impact. The reason is obvious. Given the low quality of groundwater and soil salinisation, the expected returns to investment in land would be low unless effective reclamation projects are undertaken to improve the water and soil qualities. The low impact of price changes in saline areas of both PCW and SRWN zones is reflected through cropping intensity levels that remain almost stagnant. There also appear some cross-substitution possibilities between the fresh and saline areas for sustainable crops provided the price signals are strong.

\section{Groundwater Balance}

As a result of changes in the cropping pattern, there are corresponding changes in the application of irrigation water. The model assumes fixed supplies of surface water and makes endogenous changes in the tubewell water supplies to meet the additional requirements for water. In fresh areas, the model assumes a higher rate of water extraction through tubewells as compared to saline areas, where water supplies through tubewells is kept at its minimum.

With the total water application to soil, the seepage to groundwater takes place from various sources including rain, tubewells, canals, watercourses, river, link canals, etc. Simultaneously, water is also extracted from the groundwater through 
tubewells. The net balance of groundwater, therefore, depends on the relative impact of all the inflows and outflows to groundwater. Finally, a significant amount of groundwater is lost due to evaporation, the rate of which depends on the water-table height. Table 4(a) and (b) provide information on the levels of inflows to and outflows from groundwater and show a net groundwater balance.

In fresh areas, the rates of inflows and outflows show positive growth, more so in PCW than in SRWN. However, the difference between the two reveals declining balances in both the zones. The decline in the balance confirms the earlier trends in cropping pattern changes.

The net balance of groundwater reflects higher levels of evaporation in SRWN as compared to PCW. Although both zones are discussed here in the context of fresh areas only, the average height of water-table is higher in SRWN than in PCW. As a result of higher water-tables in SRWN, the rate of evaporation almost balances out the incremental increases in groundwater levels. However, in Scenario 7, due to higher pumpage through tubewells in SRWN, there is a favourable decline in the groundwater balance.

It appears from the above that price liberalisation policies have a positive impact on groundwater balances.

In the saline areas, however, due to lower utilisation (or low investment in tubewells), there is an adverse effect on groundwater balance in both zones.

\section{Salt Additions}

The changes in the levels of salts (net of salt exports from the groundwater) are important in determining the direction of groundwater salt balances. Table 5(a) and (b) show the projected levels of salt additions to groundwater under various price scenarios.

In fresh areas, there is a decline in the addition of salts along with the higher pace of price liberalisation in both zones, though more progressively so in SRWN. However, the projections for the years 1993 and 2000 show some progressive buildup of salt levels. This clearly indicates that measures to drain out the excessive salts will have to be taken in conjunction with price liberalisation, failing which will lead towards non-sustainability of soil and water resources in the Indus Basin.

The tables also show the levels of salt accumulation in the process and clearly demonstrate that salt balances will increase in the event only price liberalisation is carried out and environmental degradation is neglected.

In the saline area, two distinctions have been made by the model, in that it divides the saline areas into areas with and without drainage.

In PCW, the drained area shows positive impact of price liberalisation across different scenarios as well as across time. It is evident from this example that the areas with drainage receive improvements in groundwater quality and build hopes 
for the sustainability of precious resources of land and water. In SRWN, no drainage has been provided yet.

The picture of undrained saline areas depicts trends similar to those in fresh areas. However, the difference in magnitude of salt accumulation is substantially higher in the case of saline areas.

\subsection{Analysis}

The analysis of price variations shows that:

- Farmers would respond to higher increases in output prices and would alter their crop mix keeping in view the relative price structure.

- There seems less sensitivity over subsidy elimination, measured in terms of changes in the cropping pattern.

- The impact of price changes leads to extensive use of land rather than intensification. The short-run gains from spreading the key inputs thinly are clearly visible, which leads to non-sustainability of land and water resources in the long run. This reflects a high discount rate for the future that the farmers might be considering while allocating resources for production purposes.

- There seems some acreage substitution possibility between fresh and saline areas, depending on the tolerance levels of crops to soil and water problems.

- The rate of investment in agricultural production seems higher in fresh areas than in saline areas. Farmers in fresh areas are more responsive to incremental changes in output prices as compared to those in saline areas.

- The groundwater balances reduce with the liberalisation of prices in fresh areas since the returns to investment in tubewells are obviously high. However, in areas with high water-tables (even in fresh areas), the higher rate of evaporation balances out inflows to groundwater and the groundwater levels remain unaltered at the end.

- With appropriate incentives, the farmers in areas of higher but fresh groundwater can be motivated for higher investments in tubewells.

- Although net addition of salts to groundwater reduces and leads to lower contamination of groundwater resources, the steady build-up of total salt deposits in groundwater will continue over time.

- The differential impact of drainage provision in the saline area suggests highly significant improvements in the salt contents along with price changes, as well as across time.

It appears from the structure as well as the pace of progress made towards structural adjustment in agriculture that a coherent relationship among various components of the structural reforms package is lacking. 
Whereas farmers are being given price signals to achieve the growth rates required for overall economic development, they are not guided and supported to achieve the targets in the manner required for the sustainability of such growth.

The environmental issues related with the structural reforms are the logical consequences that would be faced in the event components of the package are taken as valid alternates or are pursued independently.

The issue that seems pivotal in the overall analysis is of efficiency of resource use employed in the production process. For example, the loss of comparative advantage in the production of exportable commodities would not only hamper export earnings but would also lead to a decline in output prices due to the domestic market forces.

The analysis carried out clearly demonstrates that unless integrated policies embracing the issues of output prices, resource use efficiency, careful mining of groundwater resources, and drainage provisions are pursued, the enforcement of any one policy in isolation is likely to counterbalance the effects of other policies and would clearly ignore the environmental impact of one policy over the other. And this may lead to instability of the Indus Basin.

\section{POLICY RECOMMENDATIONS}

The likely impact of structural adjustment policies towards the agricultural sector seems positive in the short-run. This implies that higher output prices for agricultural commodities lead to higher production levels primarily through extensification of land use.

This impact is more likely to be in fresh groundwater areas where heavy extraction through private tubewells would provide the basis for additional cultivation. Whereas in high water-table areas such extraction is likely to reduce the impact of waterlogging, in other areas unrestricted use of tubewells may lead to rapid decline in groundwater levels, and the likely impact of contamination through intrusion of saline water from adjacent aquifers would increase.

In saline groundwater areas, the presence of drainage creates all the difference. Although the impact of higher output prices on the changes in cropping pattern is rather slow in relation to fresh groundwater areas, the drained saline areas are likely to receive a significant decline in the rate of salt deposits to groundwater.

In summary, it appears that the short- and the long-term policies designed for the development of the agricultural sector under the structural adjustment programme require close coordination. Attempts to offer international prices for agricultural commodities in haste, and without making it contingent on the improvement of agricultural infrastructure, would lead to further environmental degradation even in the short run. 
Improvement in water use efficiency, particularly at the farm level, seems to be a necessary step towards improving resource use efficiency in agriculture. In this respect, pricing of irrigation water needs to be coordinated with the efforts to establish effective water users associations. In the long run, efforts to establish water markets would be beneficial. However, this would require cautious and careful policy planning to establish private water property rights particularly in the context of the obtaining agrarian structure. Any hastily designed policy in this regard may affect the equity considerations adversely, which may not be conductive to the establishment of effective water users associations; the resulting impact on environmental degradation would hardly require any overemphasis.

In order to attain sustainable agricultural production through improvements in the levels of resource use efficiency and careful monitoring of environmental issues in agriculture, it appears necessary that, along with the policies to remove subsidies and disguised taxes from agriculture, the package of structural adjustment programme must focus on the following:

(i) Introduction of reforms to improve on-farm water and drainage management through the lessons learnt from past and existing schemes to organise farmers;

(ii) effective linkage of these reforms with the establishment of off-farm drainage schemes to be implemented by the government;

(iii) introduction of effective groundwater laws in the Indus Basin to create a basis for the subsequent establishment of individual water rights and the water markets; and

(iv) provision of scientific knowledge and improved infrastructure to farmers for improvements in resource use efficiency in order that the potential gains reposed in liberalised pricing policies are achieved and sustained. 


\section{Comments}

The author has made an admirable attempt to pick on a topic which cuts to the core of the 'trendy' economics, the Structural Adjustment Programmes (SAPs), of the post-regulationist era in developing countries' context. Hence it deserves careful probing. That problems in our agricultural sector do require a thorough restructuring is no myth; but the causes and solutions that the Bretton Woods sisters, the IMF and the World Bank, tell us are, at best, half-truths. These half-truths confound our grasp of the root causes of problems and, therefore, our ability to move towards right solutions. For example, the base ingredient of the recipe 'offered' by our saviours from Washington is the removal of farm subsidies. But it is difficult to make out how this painful sacrifice by the developing countries' farmers is going to be blissfully redeemed in a world, and particularly in the northern hemisphere, where massive protectionist subsidies have led to "butter mountains", "wine lakes", and silos bursting with surplus grain?

The author has made a mention of the possibility of an increase in rural poverty with the implementation of the SAP policy package. But his estimated variables have not included this now universally recognised legacy of SAPs. That, of course, is a limitation of the IBMR. Let us try to predicate a "dustmens"” prediction: ${ }^{1}$ Given the heavy costs of agricultural inputs and farmers' lack of bargaining power over prices of their crops, farmers are going to be plagued by mounting debts. Superfarms, on the other hand, will triumph, not because they are more efficient producers, but because of advantages that accrue to wealth and size. They have the capital to invest, and the volume necessary to stay afloat even if profits per unit shrink. Although the pressure towards the industrialisation of agriculture will end up in displacing the rural poor, they have the political clout to shape government policies in their favour. Indeed, any strategy that does not directly address these underlying dynamics of the rural economy will ultimately be punished by the backlash of greater poverty.

As for environmental degradation, the author appears to suggest that SAP is all but totally unconcerned. But, rhetoric apart, the author's chosen method of analysis, the IBRM, is no more environmentally sound than the SAP is environmentally concerned. Along with an elaborate list of ambiguities, the results merely share with us the secret, which is already out in the open, that a person

${ }^{1}$ The term refers to a quiz in The Economist of December 1984. At that time a questionnaire was sent to four ex-finance ministers in the OECD economies, four chairmen of MNCs, four students at Oxford University, and four London dustmen. They were each asked to predict economic prospects of the OECD over the next decade. With actual figures for 1994, the dustmen secured the highest score. See, "Garbage in, garbage out" The Economist, June 31995. 
exposed to excessive amounts of radiation is going to end up leukaemic. But the estimated parameters do not even begin to suggest the kind of preventive and/or curative measures to avoid and/or reverse that dreadful fate. Both SAP and IBMR, in fact, have been set up in the Green-Revolution-cum-industrial agriculture framework. They have chosen their implements through a cost-calculus derived from the positive laws of the market. But their market-oriented approach blocks us from seeing that a trade-off between environment and the enhanced performance of agriculture is not inevitable. Alternatives do exist. Indeed, the environmentally sound alternatives can even be more productive than the environmentally destructive ones. Besides, productivity, an important goal though, is not above stability and sustainability. Today, the emerging field of agroecology, built on the ecological principles of diversity, interdependence, and synergy, is applying modern science to improve rather than displace traditional farming wisdom. Agroecology relies on intercropping, crop rotations, and the mixing of plant and animal production. With intercropping, several crops grow simultaneously in the same field to help maintain soil fertility without a costly fertilizer. Poor farmers throughout the world are eager to build on this inherited land-use wisdom. Pinochet's Chile, for example, developed a model farm not much bigger than one acre, but it combines forage and row crops, vegetables, forest and fruit trees, as well as animals. The farm can supply most of the subsistence requirements of a family with scarce capital resources. Poor farmers visit the project, learn the system, and then take it to their communities to be adapted to local conditions. ${ }^{2}$ Indeed, the most rapid and sustainable rates of agricultural progress will occur where government and other institutional resources support such changes. By melding traditional wisdom with a growing scientific appreciation of our complex biological interdependence with plant and animal life, we can achieve economic security for everyone now and responsibly safeguard the resources needed by future generations.

Naheed Zia Khan

Islamia University, Bahawalpur.

\footnotetext{
${ }^{2}$ See, M. Altieri and M. Anderson, "An Ecological Basis of the Development of Alternative Agricultural System for Small Farmers in the Third World", American Journal of Alternative Agriculture, 1986 No.1, pp.33-4.
} 